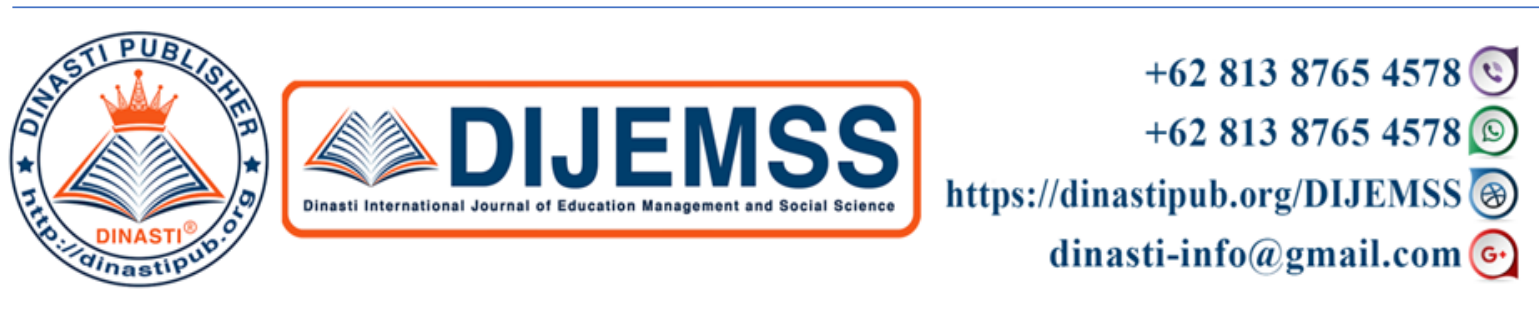

\title{
WORK ENGAGEMENT AS A MEDIATOR AUTHENTIC PERSONAL BRANDING AND GROWTH MINDSET ON ORGANIZATIONAL CITIZENSHIP BEHAVIOR
}

Rahma Arya Setiani ${ }^{1}$, Antonius Dieben Robinson Manurung ${ }^{2}$

1) Mercu Buana University, Jakarta, Indonesia

${ }^{2)}$ Mercu Buana University, Jakarta, Indonesia

\begin{tabular}{|c|c|}
\hline $\begin{array}{c}\text { ARTICLE INFORMATION } \\
\text { Received: } 13^{\text {rd }} \text { June } 2020 \\
\text { Revised: } 28^{\text {th }} \text { July } 2020 \\
\text { Issued: } 22^{\text {nd }} \text { August } 2020 \\
\text { Corresponding author: } \\
\text { aryarahma@yahoo.com } \\
\text { antonius.manurung@mercubuana.ac.id } \\
\end{array}$ & $\begin{array}{l}\text { Abstract: Each organization not only requires } \\
\text { qualified human resources but also individuals } \\
\text { who want to do things outside of their formal } \\
\text { duties to support the organization in achieving } \\
\text { success. This study aims to examine and analyze } \\
\text { work engagement as a mediator of authentic } \\
\text { personal branding and growth mindset on } \\
\text { organizational citizenship behavior at } \\
\text { Perpustakaan Nasional Republik Indonesia. This } \\
\text { study uses a quantitative approach with a structural } \\
\text { equation model using Lisrel 8.72. Using non- } \\
\text { probability (purposive sampling) in which } \\
\text { employee criteria as government employee and } \\
\text { librarian, therefore the sample is numbered, } 238 \\
\text { respondents. The findings showed that there is a } \\
\text { positive and significant effect: 1) work } \\
\text { engagement on organizational citizenship } \\
\text { behavior, 2) authentic personal branding on work } \\
\text { engagement, 3) growth mindset on work } \\
\text { engagement, 4) authentic personal branding on } \\
\text { organizational citizenship behavior with work } \\
\text { engagement as a mediator, and 5) growth mindset } \\
\text { on organizational citizenship behavior with work } \\
\text { engagement as mediator. } \\
\text { Keywords: authentic personal branding, growth } \\
\text { mindset, work engagement, organizational } \\
\text { citizenship behavior }\end{array}$ \\
\hline
\end{tabular}

\section{INTRODUCTION}

The development of information technology demands each organization to be more proactive in responding and adapting to various changes. Robbins and Judge (2017) stated that organizations need to be prepared to face changes to not lose their competitiveness. 
Regarding the developments that occur nowadays, especially in pertains to efforts for educating the nation's life, the library became one of the institutions that are expected to have an active role. For the library to be more powerful, the government in this case Perpustakaan Nasional Republik Indonesia (Perpusnas) has a position as a leader and an authority for library development in Indonesia.

Perpusnas has the vision to realize Indonesia's intelligence through the love of reading by empowering libraries. Therefore, in managing its employees, Perpusnas define employee needs analysis in transparently, objective, and accountable ways, as well as the determination of individual performance objectives in all work units. However, what about behavior that is not formally set up and does not get rewarded, this will cause a difference in the desire to show organizational citizenship behavior (OCB).

Based on the employee data of Perpusnas in 2019, noted 288 from 579 employees have a functional as a librarian. This shows the important role of the librarian as a tutor and mentor to the organization's growth strategy. In order to support the implementation of the main tasks of the librarian covering the management and service of libraries, as well as the development of the library system, as stated in PPNRI No. 11 2017, librarians need to meet the number of attendance according to an effective number of working days. Increasing OCB's librarian is expected to increase the achievement of targets from the implementation of the main librarian activities.

Further, Robbins and Judge (2017) explained that each organization not only requires qualified human resources but also requires individuals who want to do things outside of their formal duties for the organization without getting more reward, to support the organization in achieving success or named OCB. OCB in an organization can create a conducive, strengthening, and mutual filling atmosphere so that organizational stability and performance will be increased. In addition, to be able to reach the objectives the organization will surely expect its employees to behave accordingly even exceed the requirements of the organization.

However, the requirements associated with attendance level in Perpusnas still less concerned by its employees. Based on the employee attendance report of Perpusnas period July to November 2019 showed that the level of attendance (loss hours) employees in July, August, October, and November 2019 reached the number exceeds 5\%. Loss hours mean the number of working hours lost because the employee does not go to the workplace or any form of absence in the workplace with all kinds of causes such as permits, leave, and without any reason.

One of the OCB measuring scales which have the ability to measure the attitudes and behaviors named Scale of Morisson. The scale declares one of the dimensions of OCB i.e. conscientiousness which is measured based on attendance and adherence to the rules. Employee attendance report of Perpusnas shows that the level of employee's non-compliance to the organization's prevailing rules is still high. Thus, identifying in the conception of OCB on the dimension of conscientiousness is still unfulfilled and the researcher defines a temporary conclusion that the OCB at Perpusnas is still low. 
Furthermore, the researcher conducted pre-research interviews with several outstanding librarians regarding OCB and gained a temporary conclusion that the OCB level at Perpusnas was not sufficiently high and indicates problems with OCB such as the low initiative to help colleagues who are unable to attend or have overload work (altruism), weak coordination between work units causing problems in the day (courtesy), not all employees can give tolerance to colleagues (sportsmanship), low participation in activities outside working hours (civic virtue), and the trend of employees continue the conversation outside the work after the rest hour (conscientiousness).

Researcher identify using pre-research questionnaires for some of the other free variables that affect OCB with the final goal of being used as pre-research questionnaires and obtaining work engagement variables, growth mindset, and authentic personal branding is a variable that is widely chosen by 20 respondents compared to other free variables such as job satisfaction, personality, organizational climate, transformational leadership style, organizational commitment, work motivation, work environment, organizational culture, job loyalty, and organization climate.

Work Engagement is critical to the organization because it has a positive impact on employee behavior and improves organizational effectiveness and efficiency. The need for work engagement to increase the better OCB was supported by some previous research, among others Gupta (2017), Qadeer (2016) expressed a significant influence between work engagement and OCB.

Based on many literature reviews, it was found that OCB was influenced by various variables, including a growth mindset and authentic personal branding. These two factors are very important in knowledge and the ability to be possessed by individuals in developing and improving OCB. It is increasingly encouraging the researcher to conduct research that can analyze the extent and how the growth mindset and authentic personal branding affect OCB at Perpusnas.

Theoretically, employees are unaware of the overall growth mindset concept. However, in carrying out the task of the employee is faced with the demands to achieve the prevailing credit numbers. Individuals with a growth mindset will strive to improve their behavior pattern, with these efforts, not the optimal OCB could be achieved. Tanova (2017) shows a positive relationship between the level of mindset manager and OCB's employee.

In addition to the growth mindset, authentic personal branding is also a factor that affects OCB. Ahmad, Hashim, and Aaron (2016) show the importance of authentic personal branding as the key value of power for the librarian. As a professional worker, librarians need to be aware of and take the current challenge towards professional image transformation. Authentic personal branding needs to be a private mission of the librarian, followed by a private key role in the authentic personal branding criteria when meeting the user needs of the library. Ozcelik and Findikh (2015) show an insignificant internal branding effect on OCB. Commitment helps in the development of altruism, identification, and internalization of a person against the organization. In this case, internal branding helps in the creation of distinctive traits and organizations that lead to OCB. 
Apart from the initial pre-research interviews and questionnaires, the researcher also conducted advanced research to determine the real problems of OCB for employees by using questionnaires distributed to 20 respondents. From the results of the dissemination of the questionnaire, researchers describe a temporary conclusion that growth mindset and authentic personal branding have not yet understood as a factor in improving OCB through work engagement.

This study aims to examine and analyze the influences of (1) work engagement on organizational citizenship behavior at Perpusnas, (2) authentic personal branding on work engagement at Perpusnas, (3) growth mindset on work engagement at Perpusnas, (4) authentic personal branding on organizational citizenship behavior with work engagement as a mediator at Perpusnas, and (5) growth mindset on organizational citizenship behavior with work engagement as a mediator at Perpusnas.

Furthermore, this study contributes an original and meaningful to the knowledge and understanding of science-related fields. This study will fill a gap in the OCB literature by confirming the influence of authentic personal branding and growth mindset on the direct antecedents of $\mathrm{OCB}$, and not directly on $\mathrm{OCB}$, which is important in guiding organization in their efforts to promote a culture of organizational citizenship.

\section{LITERATURE REVIEW}

\section{Organizational Citizenship Behavior}

Organ introduces the term organizational citizenship behavior as a free behavior that is not part of the requirement of the formal role of employees, but it supports the effective functioning of the organization (Organ, 1997). Robbins and Judge (2017), organizational citizenship behavior is an optional behavior that is not part of the formal work of the employee and contributes to the psychological and social environment of the workplace.

The dimensions of organizational citizenship behavior by Organ (1998) are (1) altruism refers to behavior of employees in helping his co-workers who have difficulties in the situation that is facing good about the tasks in organization and personal problems of others, (2) courtesy refers to form of action aimed at preventing the emergence of problems, (3) sportsmanship refers to aspects of tolerance and individual complaints in his work, (4) civic virtue refers to behavior that indicates the responsibility on the life of organization, and (5) conscientiousness refers to the more cautious attitude and listen to the word of heart.

\section{Work Engagement}

Work engagement is a desire for involvement, commitment, passion, enthusiasm, focus, effort, and energy on its job (Bakker, 2010). The concept of attachment at work states that an engaged employee will give a big effort in his job because they know what they are doing.

The dimensions of work engagement by Schaufeli and Bakker (2004) are (1) vigor refers to the high energy level, the willingness to strive, not easily exhausted and persistent in the face of difficulties, (2) dedication refers to a feeling of meaning, enthusiasm, and pride in the work done, and feel inspired and challenged by the work, and (3) absorption, marked by concentrating fully and gladly involved in their work, so that time is fast passing and the person feels difficult to escape from their work. 


\section{Growth Mindset}

Mindset is one of the most basic beliefs about ourselves, how we see and inhabit what is considered our personality (Dweck, 2006). Mindsets are divided into two types, fixed mindset and growth mindset. Growth mindsets are based on the belief that each individual has a certain quality that can be processed through certain efforts.

The dimension of growth mindset by Manurung and Sulistiyani (2017) based on the concept of Dweck (2006), are (1) accept the challenge, which means it is not easily discouraged in doing something with deep sincerity, (2) persistent in the face of obstacles, which means it will always try and endure despite the often failure and have confidence that someday the effort will produce optimal results, (3) Seek earnest, which means having confidence in avoiding negative thoughts about failure, (4) learning from criticism, which means to assume criticism from others is learning for themselves, and (5) inspired by others which means to assume the success of others is an inspiration and valuable learning for him.

\section{Authentic Personal Branding}

Personal Branding is how someone re-brands themselves by forming a good personality for themselves either intentionally or unintentionally (Stevani \& Widayatmoko, 2017). Everyone has a personal brand, but not everyone is aware of it and does not manage effectively and consistently (Rampersad, 2008). Rampersad develops one of the personal branding models known as authentic personal branding. The model provides a framework and a guide for building, implementing, maintaining, and managing a personal brand that is authentic, distinct, relevant, consistent, concise, meaningful, crystalize, and memorable. Authentic personal branding is an authentic and strong personal identity that stimulates meaningful emotional responses in individuals regarding the quality or value it possesses in individual relationships with other individuals (Manurung, 2011).

The dimension of authentic personal branding by Manurung (2015), are (1) authenticity, i.e. individuals manifest themselves differently than their competitors, (2) integrity, i.e. individual establishes a foundation of personality and not having to be perfect, (3) consistency, i.e. individual who are endowed with authority and credibility sourced on voluntary acceptance as a leader, (4) specialization, i.e. individual concentrating on one's primary unity, talent, or achievement, (5) relevant, i.e. individuals who cling strongly with moral and behavioral code that suits the brand, (6) visibility, i.e. individual continuously raises a strong impression, so that its existence continues to be realized by the environment, (7) persistence, i.e. individuals need time to grow and develop in the process of life, and (8) goodwill, i.e. individual produces something good and survives through positive things.

\section{RESEARCH METHODS}

This research is a quantitative study that uses explanatory and causal analysis. The variables in this consisted of two exogenous variables (authentic personal branding and growth mindset), one mediator variable (work engagement), and one endogenous variable (organizational citizenship behavior). Exogenous variable is a condition considered to have effect on the reactions or research object.

The sampling technique used in this study is purposive sampling (non-probability sampling). It is done by selecting a subject based on specific criteria as core employees of 
Perpusnas or as a librarian. The population amounted to 579 employees and 238 respondents were identified as samples of research.

The data collection method uses a questionnaire with a Likert scale measured by 5 (five) point category. The five measures indicate the level to which the respondents agree with each statement, where $1=$ strongly disagree, $2=$ disagree, $3=$ neutral, $4=$ agree, $5=$ strongly agree. Data analysis techniques using SEM with Lisrel 8.72 which begins with the validity and reliability test of the construct and fit model, analysis of confirmatory factor analysis (CFA), multicollinearity test, hypothesis test, and correlation matrix of dimensions test.

\section{FINDINGS AND DISCUSSION}

The validity and reliability test results in this study have qualified as shown in Table 1.

Table 1. Validity and Reliability Test

\begin{tabular}{llll}
\hline Variable & $\begin{array}{l}\text { Standardized } \\
\text { Loading Factor } \\
\text { (SLF) } \geq \mathbf{0 . 5}\end{array}$ & $\begin{array}{l}\text { Construct } \\
\text { Reliability (CR) } \\
\mathbf{2 0 . 7 0}\end{array}$ & $\begin{array}{l}\text { Variance } \\
\text { Extracted } \\
(\mathbf{V E}) \geq \mathbf{0 . 5}\end{array}$ \\
\hline Authentic Personal Branding (APB) & 37 Items & 0.97 & 0.5 \\
\hline Growth Mindset (GM) & 13 Items & 0.94 & 0.5 \\
\hline Work Engagement (WE) & 11 Items & 0.94 & 0.6 \\
\hline OCB & 16 Items & 0.94 & 0.5 \\
\hline
\end{tabular}

Source: Lisrel 8.72 Output (2020)

The fit model test results for each variable as shown in Table 2, it states theory model of this study is fit so that the analysis can be continued.

Table 2. Goodness of Fit Test

\begin{tabular}{llllllll}
\hline Variable & $\mathbf{x}^{\mathbf{2}}$ & $\mathbf{p}$ & $\mathbf{R M S E A}$ & $\mathbf{N F I}$ & $\mathbf{R F I}$ & $\mathbf{C F I}$ & $\mathbf{N N F I}$ \\
\hline APB & 1412.92 & 0.00 & 0.078 & 0.95 & 0.95 & 0.97 & 0.97 \\
\hline GM & 123.21 & 0.00 & 0.072 & 0.97 & 0.96 & 0.98 & 0.98 \\
\hline WE & 81.71 & 0.00 & 0.075 & 0.98 & 0.97 & 0.99 & 0.98 \\
\hline OCB & 209.45 & 0.00 & 0.071 & 0.95 & 0.93 & 0.97 & 0.96 \\
\hline
\end{tabular}

Source: Lisrel 8.72 Output (2020)

Criteria: $\mathrm{RMSEA} \leq 0.08=$ Fit

NFI, RFI, CFI, NNFI $\geq 0.9=$ Fit

Further, multicollinearity test results show the value of matrix correlation between independent variables (APB and GM) amounting to $0.73<0.90$, so there is no symptom of multicollinearity in this study. While for goodness of fit test in hybrid model stated that model fit with empirical data $\left(x^{2}=141.57, p=0.99\right.$, RMSEA $=0.00, \mathrm{NFI}=0.99, \mathrm{RFI}=0.99$, $\mathrm{CFI}=1.00, \mathrm{NNFI}=1.00)$ and the structural equations are:

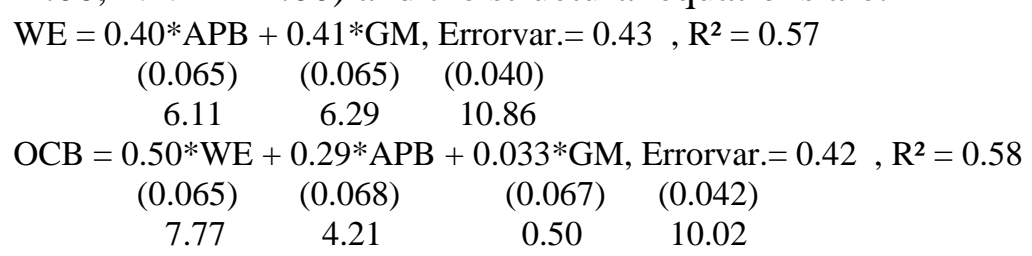




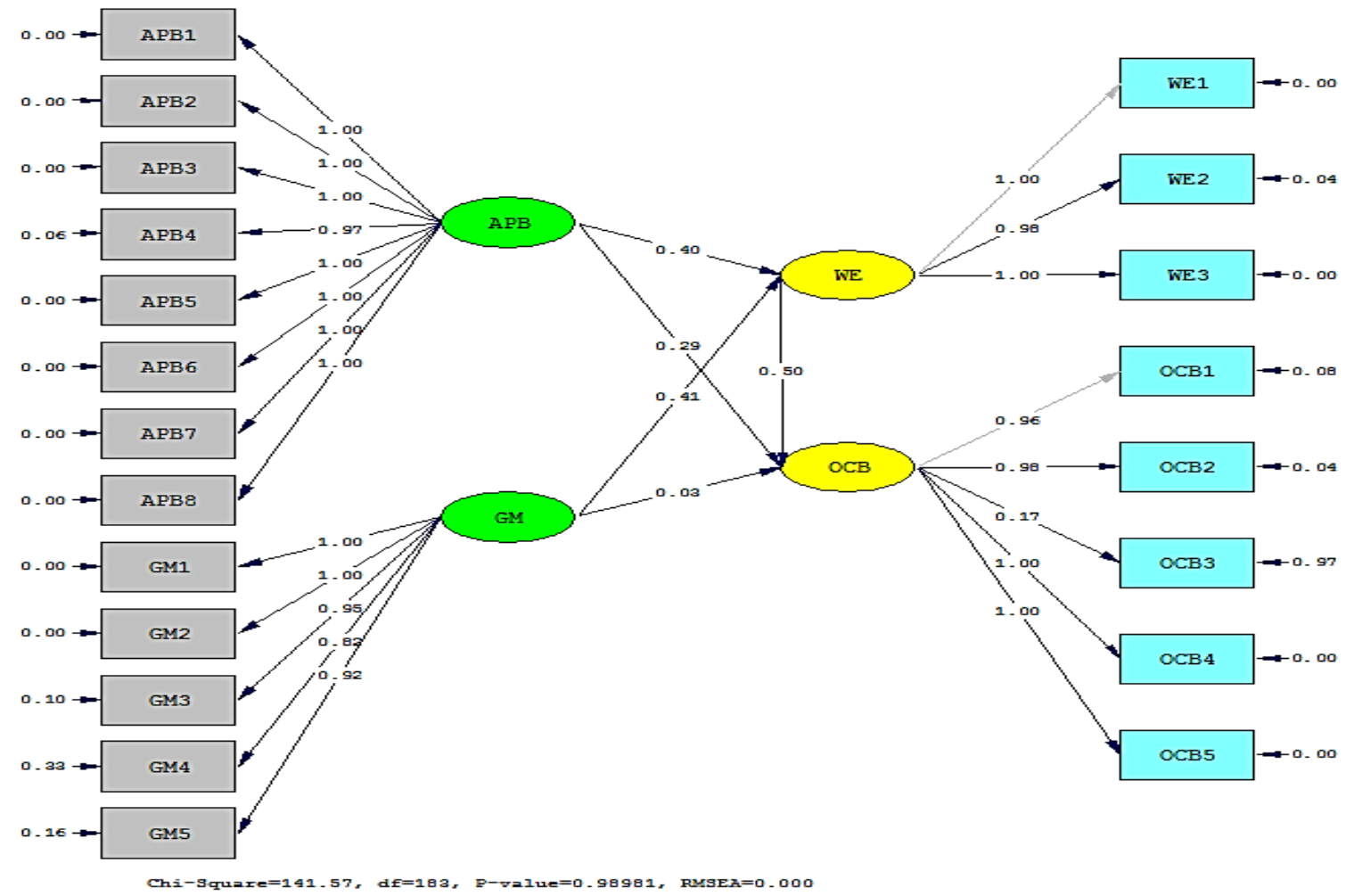

Picture 1. Hybrid Model

Source: Lisrel 8.72 Output (2020)

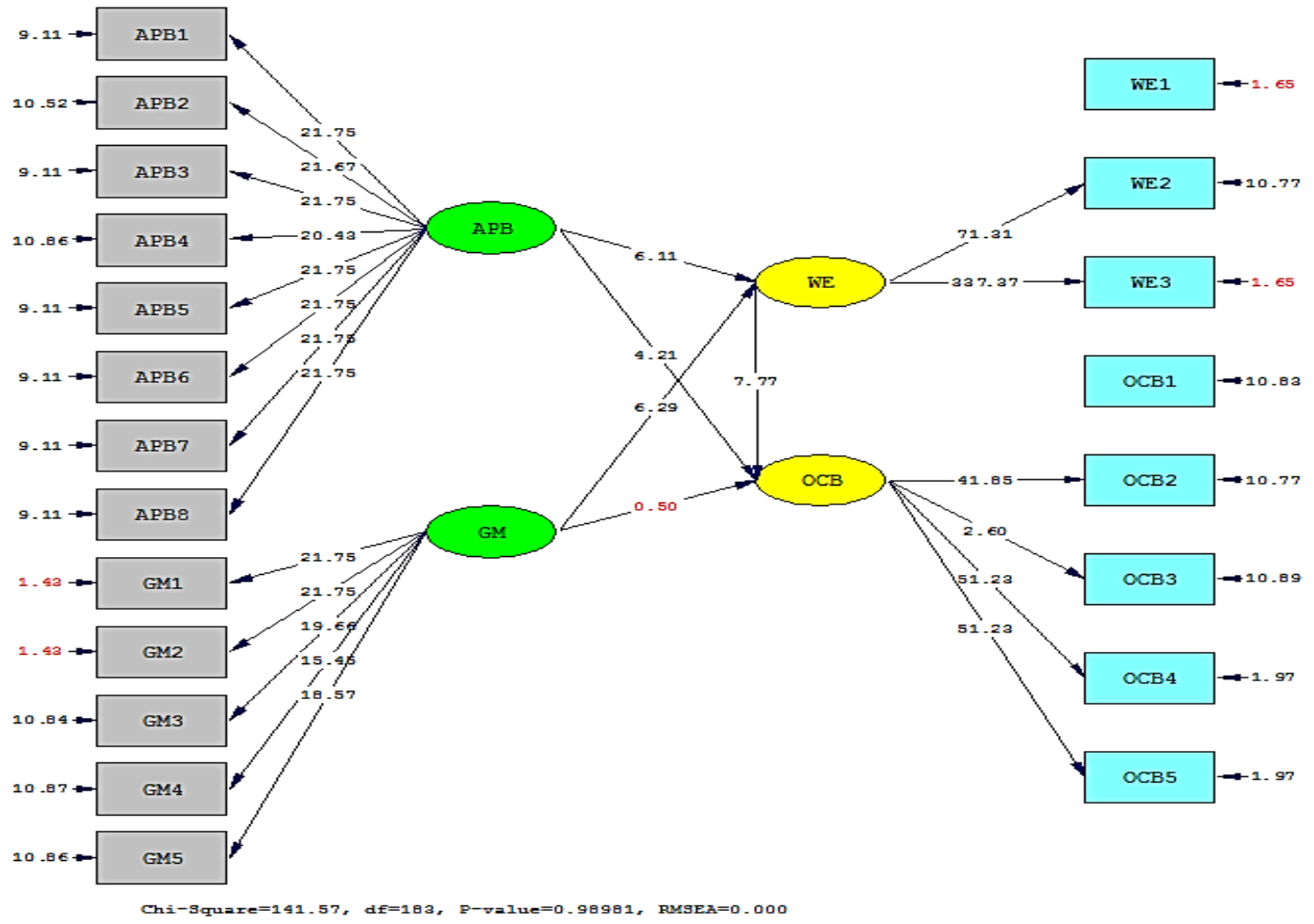

Picture 2. t-Value Model

Source: Lisrel 8.72 Output (2020) 
Hypothesis 1, 2, and 3 results as shown in Table.

Table 3. Standardized Loading Factor (SLF) and t-Values

\begin{tabular}{lll}
\hline Relationship between construction & SLF $\leq \mathbf{1}$ & T-Values $\geq \mathbf{1 . 9 6}$ \\
\hline Hypothesis 1: WE $\rightarrow$ OCB & 0.50 & 7.77 \\
\hline Hypothesis 2: APB $\rightarrow$ WE & 0.40 & 6.11 \\
\hline Hypothesis 3: GM $\rightarrow$ WE & 0.41 & 6.29 \\
\hline
\end{tabular}

Source: Lisrel 8.72 Output (2020)

The research hypothesis 1 shows the value of $\beta=0.50$ with t-value $=7.77$; where $t$ table $t \geq 1.96$, means work engagement has positive and significant effects on OCB at Perpustakaan Nasional Republik Indonesia (Perpusnas). This shows that the better work engagement of Perpusnas employees, OCB will also increase. The effects of work engagement are $50 \%$ on OCB. The results of this study are in line with the research conducted by Qadeer (2016) which states positive and significant effects of work engagement on OCB. Another study that showed the same results was done by Gupta (2017) work engagement as the mediator positively influential on the relationship between psychological capital and OCB.

The research hypothesis 2 shows the value of $\gamma=0.40$ value with $t$-value $=6.11$; where $\mathrm{t}$-table $\mathrm{t} \geq 1.96$, means authentic personal branding has positive and significant effects on work engagement at Perpusnas. This shows the better authentic personal branding of Perpusnas employees, work engagement will also increase. The effects of authentic personal branding are $40 \%$ on work engagement. The results of this study in line with the research of Ahmad, Hashim, and Aaron (2016) which involve academic librarians demonstrate the importance of authentic personal branding as one of the key values of power for the librarian. Similarly, Khedler (2018) states personal branding towards improving employees' ability to work.

The research hypothesis 3 shows the value of $\gamma=0.41$ with $t$-value $=6.29$; where $t$ table, $\mathrm{t} \geq 1.96$, means growth mindset has a positive and significant effect on work engagement of Perpusnas employees. This shows that the better growth mindset of perpusnas employees, work engagement will also increase. The effects of growth mindset are $41 \%$ on work engagement. The results of this study in line with research of Zeng, Chen, Cheung, and Peng (2019) showed an influence of positive and significant growth mindset on work engagement. Similarly, Caniel, Semejin, and Renders (2018) found a positive and significant influence between growth mindset and work engagement.

Hypothesis 4 and 5 results as shown in Table 4.

Table 4. Total Effect, Indirect Effect and Direct effect

\begin{tabular}{llll}
\hline Relationship between construction & Total Effect & Indirect Effect & Direct Effect \\
\hline Hypothesis 4: APB $\rightarrow$ OCB & 0.49 & 0.20 & 0.29 \\
\hline Hypothesis 5: GM $\rightarrow$ OCB & 0.24 & 0.21 & 0.03 \\
\hline Source: Lisrel 8.72 Output (2020) & & &
\end{tabular}

The research hypothesis 4 shows that the authentic personal branding variable directly contributes to OCB by $29 \%$, while the contribution given through the work engagement variable is $20 \%$. When compared, the value of the influence of authentic personal branding 
variables directly on OCB with work engagement, is greater than the value of the indirect effect. This means that there is a positive and significant effect of authentic personal branding on OCB with work engagement. The better authentic personal branding of Perpusnas employees, OCB will also increase with work engagement of Perpusnas employees. The results of this study are in line with Ahmad, Hashim, and Harun (2016) that authentic personal branding is one of the key values of strength for librarians. The same is stated by Rampersad (2008), when employees commit to branding, they will fulfill the promise of the characteristics created. The existence of authentic personal branding will stimulate emotional responses that are meaningful in themselves to include the quality or value they have in an individual's relationship with other individuals (Manurung, 2011). Meanwhile, the results of this study are not in line with Ozcelik and Findikh (2015) which states that internal branding has no significant effect on OCB.

The research hypothesis 5 shows growth mindset variable directly contributes to OCB by $3 \%$, while the contribution given through the work engagement variable is $21 \%$. When compared, the value of the effect of growth mindset variable indirectly on OCB with work engagement, is greater than the value of the direct effect. This means growth mindset has a positive and significant effect on OCB with work engagement. The better growth mindset of Perpusnas employees, OCB will also increase with work engagement of Perpusnas employees. The results of this study are in line with Niqab and Hanson (2019) stating that schools with a growth mindset culture show better OCB levels. Dweck (2006) also states that a positive growth mindset will give more effort to achieve better performance in this case for the achievement of OCB.

In this study, testing the correlation matrix between dimensions as shown in Table 5.

Table 5. Result of Correlation Matrix Analysis between Dimensions

\begin{tabular}{cccccccccc}
\hline & & \multicolumn{3}{c}{ Y1. WE } & \multicolumn{5}{c}{ Y2. OCB } \\
\cline { 3 - 10 } & & WE1 & WE2 & WE3 & OCB1 & OCB2 & OCB3 & OCB4 & OCB5 \\
\hline & APB1 & 0.674 & 0.647 & 0.616 & 0.589 & 0.576 & 0.162 & 0.616 & 0.619 \\
& APB2 & 0.652 & 0.609 & 0.572 & 0.557 & 0.569 & 0.089 & 0.608 & 0.604 \\
X1. & APB3 & 0.659 & 0.625 & 0.638 & 0.632 & 0.623 & 0.142 & 0.645 & 0.652 \\
APB & APB4 & 0.669 & 0.640 & 0.601 & 0.637 & 0.621 & 0.108 & 0.665 & $\mathbf{0 . 6 6 7}$ \\
& APB5 & 0.636 & 0.612 & 0.608 & 0.585 & 0.577 & 0.143 & 0.592 & 0.602 \\
& APB6 & 0.618 & 0.581 & 0.572 & 0.572 & 0.597 & 0.189 & 0.603 & 0.600 \\
& APB7 & $\mathbf{0 . 6 8 7}$ & 0.666 & 0.627 & 0.613 & 0.602 & 0.142 & 0.636 & 0.636 \\
& APB8 & 0.668 & 0.647 & 0.618 & 0.596 & 0.604 & 0.184 & 0.629 & 0.633 \\
\hline
\end{tabular}




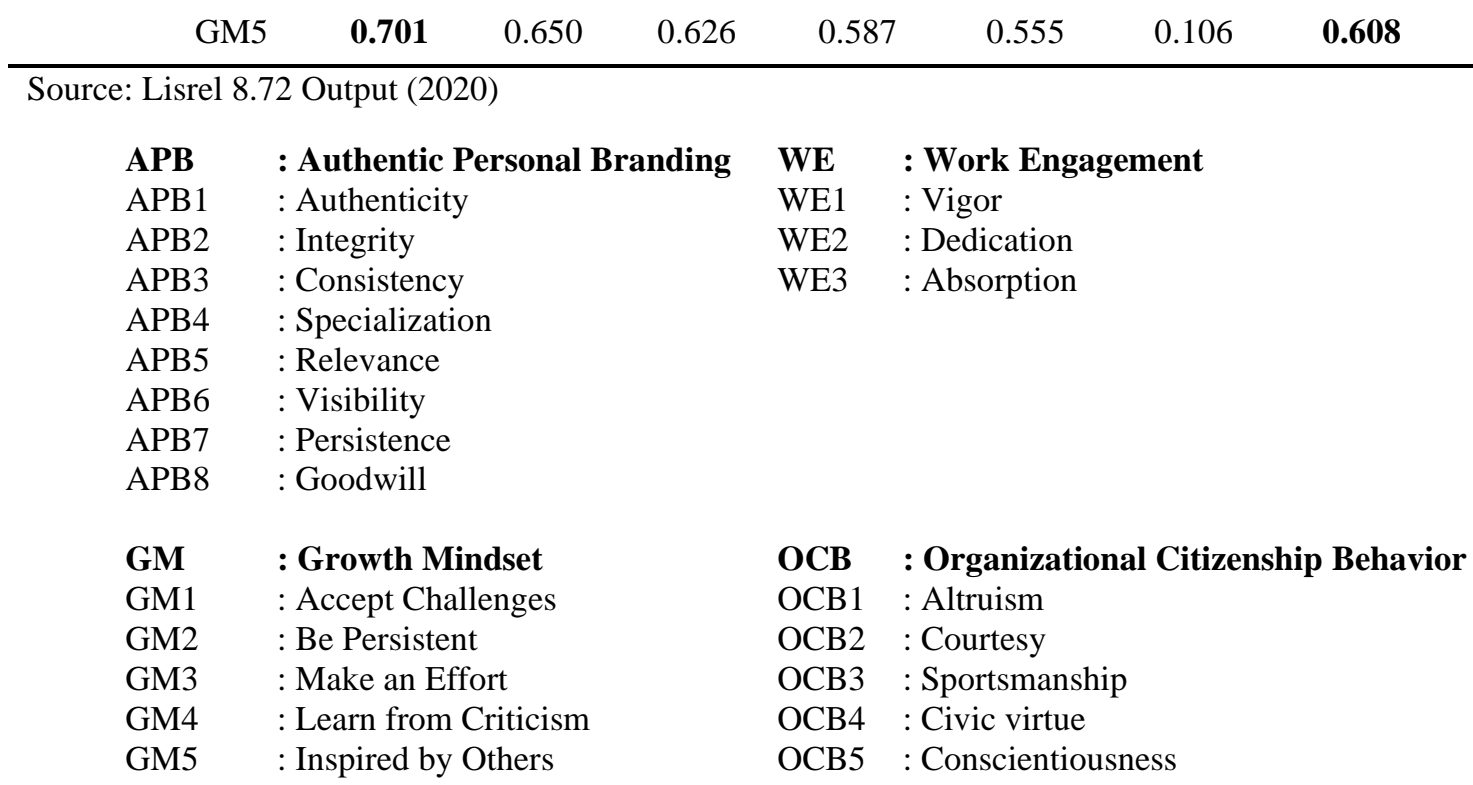

Correlation matrix analysis between dimensions results in Table 5 show (1) dimension of authentic personal branding variable that has the greatest relationship is persistence (APB7) with work engagement variable on vigor (WE1) with a correlation coefficient of 0.687 (has a relationship with the category of "strong"), (2) dimension of growth mindset variable that has the greatest relationship is inspired by others (GM5) with work engagement variable on vigor (WE1) with a correlation coefficient of 0.701 (has a relationship with the category of "strong"), (3) dimension of authentic personal branding variable that has the greatest relationship is specialization (APB4) with organization citizenship behavior variable on conscientiousness (OCB5) with a correlation coefficient of 0.667 (has a relationship with the category of "strong"), and (4) dimension of growth mindset variable that has the greatest relationship is inspired by others (GM5) with organization citizenship behavior variable on civic virtue (OCB4) and conscientiousness (OCB5) with a correlation coefficient of 0.608 (has a relationship with the category of "strong").

\section{CONCLUSION AND SUGGESTION}

Based on data analysis, the following research conclusions are (1) work engagement has a positive and significant effect on organizational citizenship behavior at Perpusnas. The more employees have work engagement, the more committed they are in the creation of organizational citizenship behavior, (2) authentic personal branding has a positive and significant effect on work engagement at Perpusnas. The more employees have authentic personal branding, the more they have good work engagement in themselves, (3) growth mindset has a positive and significant effect on work engagement at Perpusnas. The more employees have a growth mindset, the more they have a good work engagement in themselves, (4) authentic personal branding has a positive and significant effect on organizational citizenship behavior at Perpusnas with work engagement as a part mediator. The better authentic personal branding, organizational citizenship behavior will also increase with work engagement at Perpusnas, and (5) growth mindset has a positive and significant 
effect on organizational citizenship behavior at Perpusnas with work engagement as a full mediator. The better growth mindset, organizational citizenship behavior will also increase with work engagement at Perpusnas.

The following theoretical and practical suggestions that are expected to be useful for the development of research or further scientific studies and especially for organizations are (1) the development of research subjects and objects need to be developed by making research such as in Regional Libraries, Schools, Universities, or other Institutions so that research results are increasingly heterogeneous, (2) qualitative research approach or mix method should be tried as an alternative in the same research theme by involving librarians who are members of the Librarian Association, (3) comprehension of organizational citizenship behavior theory and looking for another variables that influence organizational citizenship behavior such as extrinsic motivation, intrinsic motivation, leadership style, and so on, (4) Perpusnas should develop personal branding of librarians to be more authentic as an effort to improve organizational citizenship behavior behavior and pay attention to librarians to stay motivated in growth mindset concept in themselves so that organizational citizenship behavior behavior is generated better. Besides, Perpusnas should improve the level of work engagement through an appreciation program such as an outstanding librarian award. This is because work engagement has a direct and significant influence on organizational citizenship behavior and mediates authentic personal branding and growth mindset on organizational citizenship behavior.

\section{REFERENCE}

Ahmad, R., Hashim, L., \& Harun, N. (2016). "Criteria for effective authentic personal branding for academic librarians in universiti sains malaysia libraries". Procedia Social and Behavioral Sciences. Vol. 224, pp. 452-458.

Bakker, A.B. (2010). Work engagement: A handbook of essential theory and research. New York: Psychology Press.

Caniel, M.C.J., Semejin, J.H., \& Renders, I.H.M. (2018). "Mind the mindset! the interaction of proactive personality, transformational leadership and growth mindset for engagement at work". Career Development International. Vol. 23 No. 1, pp. 48-66.

Dweck, C.S. (2006). Change your mindset change your life. Jakarta: PT Serambi Ilmu Semesta.

(2006). Mindset: The new psychology of success. New York: Random House Incorporated.

. (2009). "Mindset: Developing talent through a growth mindset". Olympic Coach. Vol. 21 No. 1, pp. 4-7.

Elmi, F. (2019). Organizational citizenship behavior dalam perspektif Islam (aplikasi takwa). Mix Jurnal Ilmiah Manajemen, 9(2), 298-311. 
Gupta, M. (2017). "Impact of psychology capital on organizational citizenship behavior: Mediation by Work Engagement". Journal of Management Development. Vol. 36, Issue. 7, pp. 973-983.

Khedher, M. (2018). "Conceptualizing and researching personal branding effects on the employability". Journal of Brand Management. https://doi.org/10.1057/s41262-0180117-1.

Manurung, A.D.R. (2011). Authentic personal branding sebagai mediator kepemimpinan heroik dan organisasi pembelajaran terhadap prestasi kerja (pada para pemimpin bisnis pemasaran Jaringan Tianshi dengan support system unicore). Disertasi: Jakarta. Universitas Persada Indonesia YAI.

. (2015). "The influence of heroic leadership and learning organization to work achievement with authentic personal branding as mediator". Mediterranean Journal of Social Sciences. Vol. 6, No. 5, S5.

. (2016). "alat ukur skala authentic personal branding”. Diterbitkan: Kementerian Hukum dan Hak Asasi Manusia. No. HKI.2-HI.01.04-41.

Manurung, A.D.R., Damaris, A., \& Wimbaningrum, N. (2017). “Authentic personal branding as a mediator of influence of heroic leadership and positive psychological capital on work life quality". Actual Problem of Economics. Vol. \#4 (190), pp. 134-142.

Manurung, A.D.R., \& Sulistiyani, N. (2017). Pengaruh konsep diri dan growth mindset terhadap orientasi kesehatan pada karyawan PT. Kenko Indonesia Wilayah Jakarta. Skripsi: Jakarta. Universitas Mercu Buana.

Nawangsari, L. C., \& Sutawidjaya, A. H. (2018, December). The impact of human resources practices affecting organization citizenship behaviour with mediating job satisfaction in University. In 3rd Annual International Seminar on Transformative Education and Educational Leadership (AISTEEL 2018). Atlantis Press.

Niqab, M., Hanson, J., et al (2019). "Measuring organizational citizenship behaviors (ocb) in secondary schools in pakistan and a comparison with factors of a school growth mindset culture". International Journal of Learning and Development. Vol. 9 No. 2, pp. 83-115.

Organ, D.W. (1998). Organizational citizenship behavior: The good soldier syndrome. Lexington: Lexington Books.

Ozcelik, G., \& Findikh, M.A. (2015). "The relationship between internal branding and organizational citizenship behavior: the mediating role of person-organization fit". Procedia - Social and Behavioral Sciences. Vol. 150, pp. 1120-1128.

Qadeer, F. (2016). "Linking passion to organizational citizenship behavior and employee performance: the mediating role of work engagement". Pakistan Journal of Commerce and Social Science. Vol. 10 No. 2, pp. 316-334.

Rampersad, H.K. (2008). Authentic personal branding. Jakarta: Pengembangan Eksekutif;

Riyanto, S., Ariyanto, E., \& Lukertina, L. (2019). Work life balance and its influence on employee engagement " $\mathrm{Y}$ " generation in courier service industry. International Review of Management and Marketing, 9(6), 25-31. 
Robbins, S.P., \& Judge, T.A. (2017). Perilaku organisasi buku i dan ii edisi 12, Penerjemah Diana Angelica, dkk. Jakarta: Salemba Empat.

Schaufeli, W.B., \& Bakker, A.B. (2004). "Job demands, job resources, and their relationship with burnout and engagement: A multi-sample study". Journal of Organizational Behavior. Vol. 25 No. 3, pp.293-315.

Sekaran, U \& Bougie, R. (2017). Metode penelitian untuk bisnis edisi 6. Jakarta: Salemba Empat.

Shanker, M. (2018). "Organizational citizenship behavior in relation to employees' intention to stay in Indian Organizations". Business Process Management Journal. DOI 10.1108/BPMJ-02-2018-0048.

Stevani \& Widayatmoko. (2017). Kepribadian dan komunikasi Susi Pudjiastuti dalam membentuk personal branding. Jurnal Komunikasi. Vol. 9, No. 1, hal 65-74.

Tanova, A.O.C. (2017). "Manager mindset and employee organizational citizenship behaviors". International Journal of Contemporary Hospitality Management. Vol. 29 Issue. 1 pp. 589-606.

Zeng, G., Chen, X., Cheung, H.Y., \& Peng, K. (2019). “Teacher's growth mindset and work engagement in the chinese educational context: well-being and perseverance of effort as mediators". Frontiers in Psychology. Vol. 10, Article. 839. 